\title{
Protein profiling of plasma proteins in dairy cows with subclinical hypocalcaemia
}

\author{
Ziling Fan, Shi Shu, Chuchu Xu, Xinhuan Xiao, Gang Wang, Yunlong Bai, Cheng Xia*', Ling Wu, Hongyou Zhang, \\ Chuang $X u$ and Wei Yang
}

\begin{abstract}
Subclinical hypocalcaemia (SH) is an important metabolic disease in dairy cows that has a serious impact on production performance. The objective of this study was to investigate novel aspects of pathogenesis using proteomics technology to identify proteins that are differentially expressed in diseased and healthy animals. Dairy cows were divided into an SH group $(T, n=10)$ and a control group $(C, n=10)$ based on plasma calcium concentration. A total of 398 differentially expressed proteins were identified, of which 265 proteins were overlapped in the two parallel experiments. Of these, 24 differentially expressed proteins were statistically significant. Gene Ontology analysis yielded 74 annotations, including 7 cellular component, 55 biological process and 12 molecular function categories. Bioinformatics analysis indicated that calcium regulation, immune and inflammatory response, blood coagulation and complement pathway were all related to SH. Our iTRAQ/LC-MS/MS (isobaric tags for relative and absolute quantification/liquid chromatography-mass spectrometry/mass spectrometry) approach proved highly effective for plasma protein profiling of dairy cows with SH, and the results pave the way for further studies in this area.
\end{abstract}

Keywords: Dairy cows, iTRAQ, LC-MS/MS, Proteomics, Subclinical hypocalcaemia

\section{Findings}

Animal husbandry, and dairy farming in particular, has grown considerably in China in recent years, and is now a major industry. However, the increase in dairy farming has been accompanied by the proliferation of metabolic diseases that have a significant deleterious effect on the production performance of dairy cows. Subclinical hypocalcaemia $(\mathrm{SH})$ is one such metabolic disease that has no obvious clinical signs and can therefore be easily ignored. Biochemical tests show that the blood calcium (Ca) concentration of dairy cows with $\mathrm{SH}$ is between 1.38 and $2.00 \mathrm{mmol} / \mathrm{L}$. This disease increases the risk of other perinatal diseases due to the reduced blood $\mathrm{Ca}$ concentration and muscle contractive capacity [1]. SH has been studied using proteomics approaches based on SELDI-TOF-MS (surface-enhanced laser desorption/ ionization-time of flight-Mass spectrometry) [2, 3], 2DDIGE (fluorescence two-dimensional differential gel electrophoresis) combined with MALDI-TOF-MS (matrix-

\footnotetext{
* Correspondence: xcwlxyf2014@163.com

Ziling Fan and Shi Shu are co-first authors.

Department of College of Animal Science and Veterinary Medicine,

Heilongjiang Bayi Agricultural University, Daqing 163319, China
}

assisted laser desorption/ionization-time of flight-mass spectrometry) [4] and metabolomics based on ${ }^{1} \mathrm{H}-\mathrm{NMR}$ (1hydrogen-nuclear magnetic resonance) [5]. However, these techniques have their limitation on studying differentially expressed proteins in dairy cows with $\mathrm{SH}$. And our iTRAQ/LC-MS/MS technique can obtain more comprehensive information on differentially expressed proteins, which can further explore the pathogenesis and preventive methods of SH in dairy cows. In the present study, we used iTRAQ (isobaric tags for relative and absolute quantitation) to isotopically label and simultaneously analyze protein expression in diseased and healthy animals [6]. The objective of this study was to identify differentially expressed proteins in plasma from dairy cows with SH using iTRAQ/LC-MS/ MS combined with bioinformatics analysis to provide novel insight into the pathogenesis of $\mathrm{SH}$.

\section{Materials and methods}

Experimental animals

This experiment was conducted in strict accordance with the recommendations in the Guide for the Care and Use of Laboratory Animals of the National Institutes of Health located in United States. All experimental 
animals were treated according to the International Guiding Principles for Biomedical Research Involving Animals.

All cows were obtained from an intensive dairy farm located in Heilongjiang Province. All diets were in accordance with the Chinese standards for cattle breeding. All cows were fed a total mixed ration during the dry period, which consisted of $2.02 \mathrm{~kg}$ of concentrated feed, $17.37 \mathrm{~kg}$ of silage maize, and $4.2 \mathrm{~kg}$ of leymus chinensis, with a dry matter content of $42.9 \%$. The net energy for dry cow of this diet was $1.3 \mathrm{Mcal} / \mathrm{kg} \mathrm{DM}$. The nutritional content was $12.89 \%$ crude protein, $2.83 \%$ fat, 49.21\% neutral detergent fibre, $27.47 \%$ acid detergent fibre, and $71.71 \mathrm{~g}$ of $\mathrm{Ca}$ and $42.75 \mathrm{~g}$ of $\mathrm{P}$ per cow per day. The major mineral content was $91.81 \mathrm{mg}$ of zinc, $59.29 \mathrm{mg}$ of manganese, $16.60 \mathrm{mg}$ copper, $0.44 \mathrm{mg}$ of iodine, $0.25 \mathrm{mg}$ of cobalt and $0.79 \mathrm{mg}$ of selenium per cow per day. The dietary cation anion difference (DCAD) was $91 \mathrm{meq} / \mathrm{kg}$ DM. All cows were fed the same diet during the dry period.

Experimental Holstein dairy cows of a similar age, parity and body condition were selected. In total, 10 animals with $\mathrm{SH}$ were placed in $\mathrm{T}$ group, and 10 healthy cows were placed in $\mathrm{C}$ group. Cows were considered to be suffering from $\mathrm{SH}$ if within 1-3 days postpartum they displayed no obvious clinical signs but exhibited a plasma Ca concentration between 1.38 and $2.00 \mathrm{mmol} /$ L. In addition, both groups contained only clinically normal cows in every other respect. In order to minimize individual differences between samples, 5 plasma samples from each group were mixed to generate one hybrid sample, and this was labelled using an iTRAQ kit and used in subsequent experiments. Basic information on dairy cows and experimental design are listed in Table 1.

\section{Collection of blood samples}

All blood samples were obtained within $6 \mathrm{~h}$ of calving from tail veins of cows in the early morning, anticoagulated with heparin and immediately centrifuged at $3000 \times g$ for $10 \mathrm{~min}$ at room temperature. The plasma were transferred to eppendorf tubes $(1.5 \mathrm{~mL})$ and stored at $-80{ }^{\circ} \mathrm{C}$ until needed.

\section{Measurement of plasma Ca concentration}

The plasma $\mathrm{Ca}$ concentration was measured using an automatic biochemical analyser (modular DPP, Roche Diagnostics $\mathrm{GmbH}$ ) and a Ca plasma kit (651564-01, Roche Diagnostics $\mathrm{GmbH}$ ).

\section{Elimination of high abundance proteins from plasma samples}

In order to enrich low abundance proteins, high abundance proteins were eliminated according to the operating instructions supplied with the ProteoMiner kit (BioRad, USA, catalog\#s163-3007) following thawing and mixing of samples. Protein concentration was measured by the Bradford method to determine the loading quantity, and eliminated high abundance proteins were detected by SDS-PAGE (sodium dodecyl sulfate polyacrylamide gel electrophoresis).

\section{iTRAQ labelling}

Plasma samples $(100 \mu \mathrm{L})$ digested with protease were mixed with trypsase (dissolved in precooled deionized water) at a ratio of $20: 1$, digested again at $27{ }^{\circ} \mathrm{C}$ overnight, and centrifuged at $1000 \times g$ for $30 \mathrm{~s}$ at $4{ }^{\circ} \mathrm{C}$. iTRAQ reagent (in each tube) was dissolved completely in $70 \mu \mathrm{L}$ of ethanol, and centrifuged at $1000 \times g$ for $30 \mathrm{~s}$ at $4{ }^{\circ} \mathrm{C}$. Treated plasma samples were labelled with treated iTRAQ reagent following standing for $2 \mathrm{~h}$, and labelled plasma samples $(1 \mu \mathrm{L})$ were vortexed and evaporated to dryness in vacuum. Information on iTRAQ labelling is shown in Table 1.

\section{Strong cation exchange (SCX) and high $\mathrm{pH}$ reverse fractionation}

Peptides in dried plasma samples were dissolved in loading buffer $\left(10 \mathrm{mmol} / \mathrm{L} \mathrm{K}_{3} \mathrm{PO}_{4} \mathrm{pH} 3.0,25 \% \mathrm{ACN}\right.$ ) (acetonitrile) and the $\mathrm{pH}$ was adjusted to 3. A PolyLC SCX chromatographic column $(10 \mathrm{~mm}$ id $\times 14 \mathrm{~mm}, 12 \mu \mathrm{m}$, 300 A; PolyLC Inc, Columbia, MD, USA) was

Table 1 Information on experimental animals and iTRAQ labelling

\begin{tabular}{|c|c|c|c|c|}
\hline & \multicolumn{2}{|l|}{$\mathrm{SH}(\mathrm{T})$} & \multicolumn{2}{|l|}{ Control (C) } \\
\hline & $\mathrm{T} 1$ & $\mathrm{~T} 2$ & $\mathrm{C} 1$ & $C 2$ \\
\hline Age & $3.2 \pm 0.84$ & $3.2 \pm 0.84$ & $2.8 \pm 0.84$ & $2.8 \pm 0.84$ \\
\hline Parity & $5.2 \pm 0.84$ & $5.2 \pm 0.84$ & $4.8 \pm 0.84$ & $4.8 \pm 0.84$ \\
\hline $\mathrm{BCS}$ & $3.25 \pm 0.05$ & $3.15 \pm 0.06$ & $3.20 \pm 0.07$ & $3.25 \pm 0.06$ \\
\hline Plasma Ca (mmol/L) & $1.91 \pm 0.08^{\mathrm{A}}$ & $1.93 \pm 0.08^{\mathrm{A}}$ & $2.24 \pm 0.08^{B}$ & $2.26 \pm 0.09^{B}$ \\
\hline iTRAQ kit & 114 & 115 & 116 & 117 \\
\hline
\end{tabular}

SH subclinical hypocalcaemia, $B C S$ body condition score, $C a$ calcium, iTRAQ isobaric tags for relative and absolute quantification. SH cows, $n=10$; Control cows, $n=10 ; \mathrm{T} 1, \mathrm{~T} 2, \mathrm{C} 1, \mathrm{C} 2, n=5 ;$ mean \pm standard deviation. The same capital letter in a row indicates no significant difference between groups ( $P>0.05)$. Different capital letters in a row indicate highly significant differences between groups $(P<0.01)$ 
equilibrated in loading buffer, and $400 \mu \mathrm{g}$ of sample was loaded onto the column and eluted with $2 \mathrm{ml}$ loading buffer. Eluted peptides were evaporated to dryness in vacuum and separated by high $\mathrm{pH}$ reverse fractionation. Following drying in vacuum, peptides were dissolved in $150 \mu \mathrm{l}$ of $2 \% \mathrm{ACN} / 0.5 \% \mathrm{FA}$ (formaldehyde) and stored at $-80{ }^{\circ} \mathrm{C}$ until needed for MS.

\section{Nano LC-MS/MS separation and MS identification}

Samples were separated using an UltiMate 3000 RSLCnano nano-litre flow rate LC system (Thermo-Dionex, Sunnyvale, CA, USA), and MS was performed with a LTQ Orbitrap Velos (Thermo-Fisher Scientific, San Jose, CA, USA). Raw data were collected by Xcalibur 2.1 operation software (Thermo-Fisher Scientific), corrected using Proteome Discoverer 1.3 (Thermo) and exported as MGF formatted files. Mascot 2.3.02 (Matrix Science, Boston, MA, USA) was used for database searching, and processed data were used to search the NCBInr Bovine RefSeq database that contained 71,248 protein sequences when downloaded on April 11, 2011. The error rate of peptide and protein identification was $<5 \%$, and at least two unique peptides were identified for each protein. All potential SH-related proteins were subjected to quantitative analysis by Proteome Discoverer 1.3 according to the pseudo-molecular- ion intensity obtained in the peptides report. The ratio of the quasi-molecular-ion intensity (114/116 and 115/117) was determined by each protein present in both $\mathrm{T}$ and $\mathrm{C}$ group.

\section{Statistical analysis}

The age, parity, body condition score [7] and plasma Ca concentration of cows between groups were analyzed by one-way ANOVA using SPSS version 19.0 (IBM, Armonk, NY, USA). Differentially expressed proteins were analyzed by Venn analysis (VENN 2.1, http://bioinfogp.cnb.csic.es/ tools/venny/) and Gene Ontology (GO) analysis (GOTERM_BP_ALL,GOTERM_CC_ALL, GOTERM _MF_ ALL) using DAVID bioinformatics analysis software (v6.7, http://david.abcc.ncifcrf.gov/home.jsp).

\section{Results}

\section{Information on experimental animals}

The age, parity, body condition score and plasma Ca concentration of $\mathrm{SH}$ and control cows are listed in Table 1. The observed decrease in the plasma Ca concentration between $\mathrm{T}$ and $\mathrm{C}$ groups was the only significant difference.

\section{Venn analysis of experimental results}

Data (114/116 and 115/117) were collected in two parallel experiments, and 365 and 298 proteins were identified in each parallel experiment, which resulted in 398 differentially expressed proteins. Venn analysis of all 398 differentially expressed proteins confirmed 265 overlapping proteins, and 100 and 33 unique proteins in each parallel experiment (Fig. 1). Overlapping proteins accounted for $66.58 \%$ of all identified proteins.

\section{Identification of differentially expressed proteins}

Mean values of the fold change in expression were calculated for proteins overlapping (265) in the two parallel experiments. A mean value greater than 1.5 was considered up-regulated, and a mean value lower than 0.67 was considered down-regulated. As a result, 24 differentially expressed proteins were identified, comprising 21 that were up-regulated and 3 that were down-regulated (Tables 2 and 3).

\section{Bioinformatics analysis of differentially expressed proteins}

All 24 differentially expressed proteins were subjected to function enrichment analysis of cell component, molecular function and biological process categories (Fig. 2). In total, 74 annotations were obtained, comprising 7 cell components, 12 molecular functions and 55 biological processes.

GO analysis revealed that the most highly represented biological process terms were inflammatory reaction, immunoreaction and resistance function', while the top molecular function terms were 'cell' and 'molecular', and the dominant cell component terms were 'extracellular domain' and 'lipoprotein'.

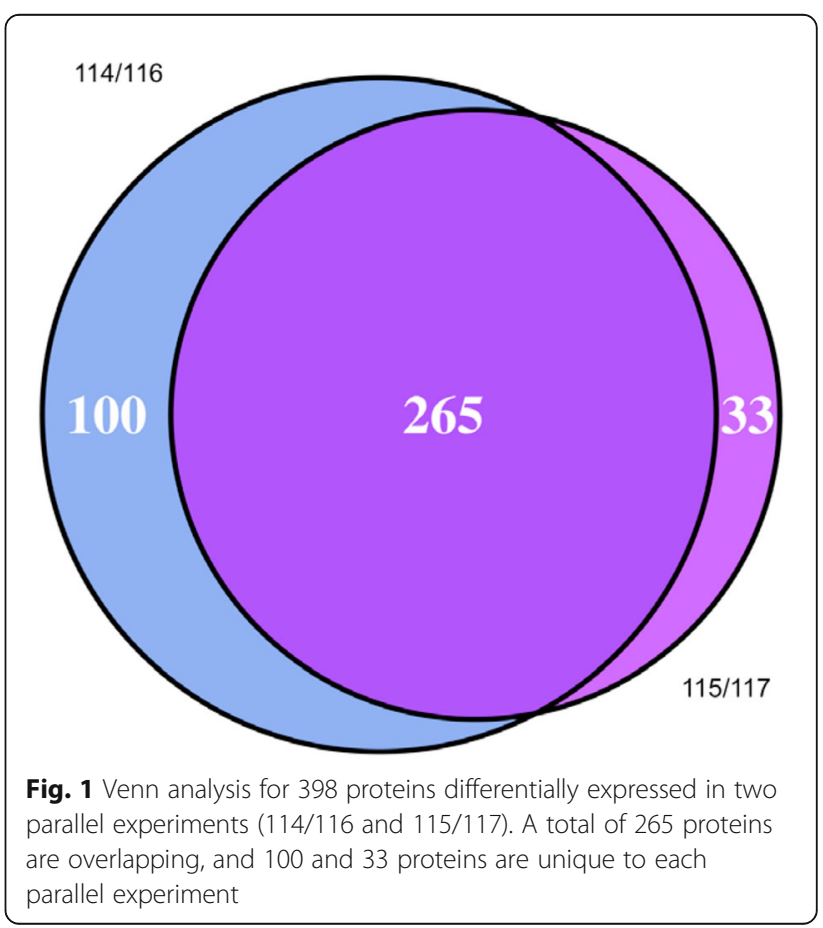




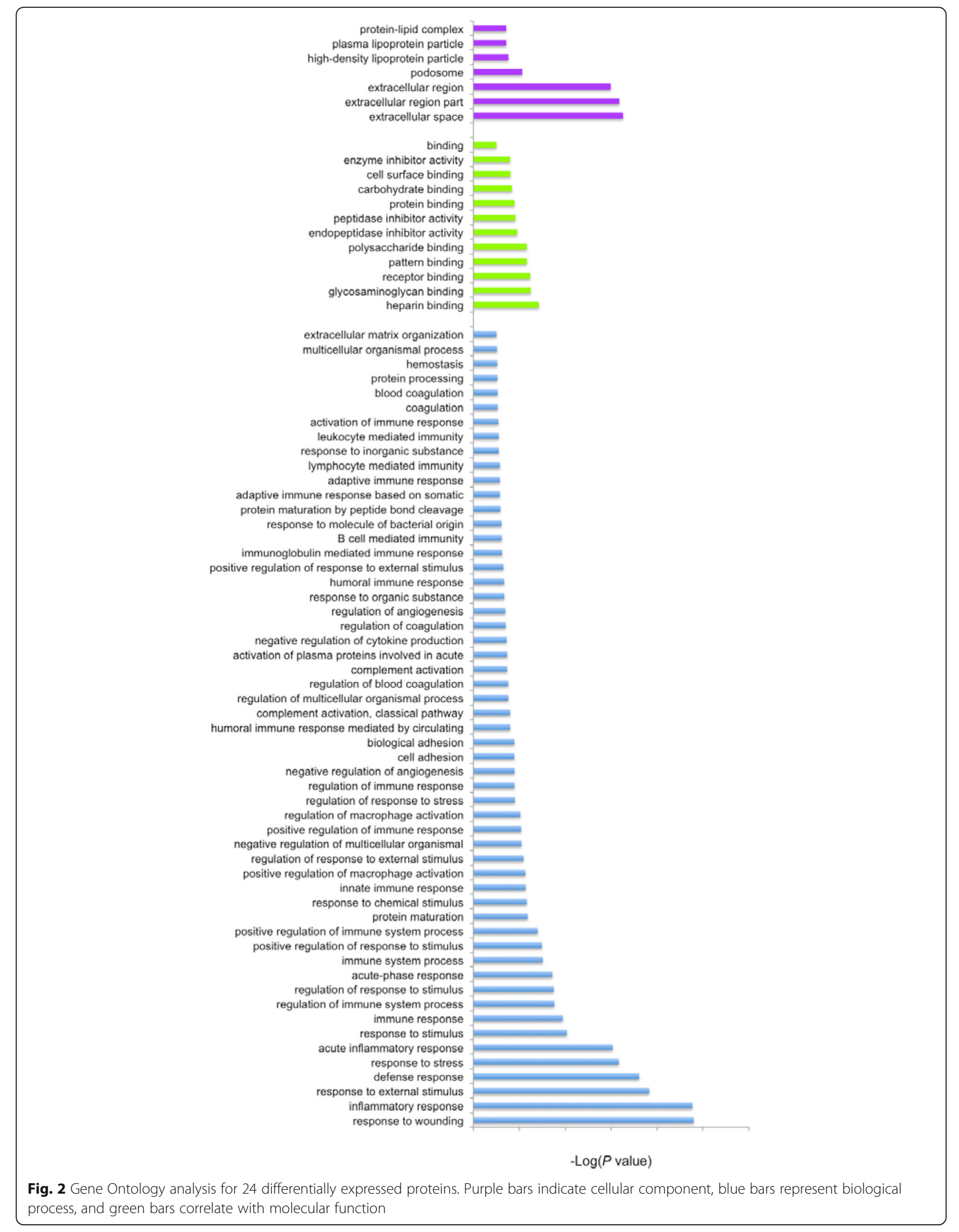


Table 2 Proteins up-regulated among overlapping proteins

\begin{tabular}{|c|c|c|}
\hline Gl number & Protein name & Mean fold change \\
\hline 78369352 & Complement component C9 precursor [Bos taurus] & 1.55 \\
\hline 94966809 & Serum amyloid A-4 protein precursor [Bos taurus] & 1.57 \\
\hline 27807167 & Peroxiredoxin-6 [Bos taurus] & 1.60 \\
\hline 358420568 & PREDICTED: complement C4-A-like [Bos taurus] & 1.62 \\
\hline 155372183 & Carboxypeptidase N subunit 2 precursor [Bos taurus] & 1.62 \\
\hline 83035071 & Fermitin family homolog 3 [Bos taurus] & 1.66 \\
\hline 77735579 & Fibrinogen-like protein 1 precursor [Bos taurus] & 1.66 \\
\hline 27806297 & Flavin reductase (NADPH) [Bos taurus] & 1.66 \\
\hline 155372051 & Tropomyosin alpha-4 chain [Bos taurus] & 1.68 \\
\hline 115497210 & Complement C1s subcomponent precursor [Bos taurus] & 1.71 \\
\hline 164450479 & Kininogen-2 isoform I precursor [Bos taurus] & 1.73 \\
\hline 154707858 & Cadherin-17 precursor [Bos taurus] & 1.75 \\
\hline 61888874 & Transgelin-2 [Bos taurus] & 1.79 \\
\hline 78042516 & Phospholipid transfer protein precursor [Bos taurus] & 1.81 \\
\hline 221136893 & C-reactive protein precursor [Bos taurus] & 1.90 \\
\hline 95147666 & Periostin precursor [Bos taurus] & 1.93 \\
\hline 114051505 & Serpin $\mathrm{H} 1$ precursor [Bos taurus] & 2.02 \\
\hline 84579853 & Lipopolysaccharide-binding protein precursor [Bos taurus] & 2.34 \\
\hline 41386760 & Monocyte differentiation antigen CD14 precursor [Bos taurus] & 2.59 \\
\hline 115497340 & Serum amyloid A protein precursor [Bos taurus] & 4.54 \\
\hline 94966763 & Haptoglobin precursor [Bos taurus] & 8.65 \\
\hline
\end{tabular}

Gl (genInfo identifier). Proteins with a mean value greater than 1.5 are considered up-regulated, while those with a mean value lower than 0.67 are considered down-regulated

\section{Discussion}

In this study, iTRAQ and LC-MS/MS were used for plasma protein profiling of $\mathrm{SH}$ in dairy cows. A total of 398 differentially expressed proteins were identified, of which 265 proteins overlapped in the two parallel experiments. Of these, 24 differentially expressed proteins were statistically significant, of which 21 were up-regulated and 3 were down-regulated. Based on bioinformatics analysis, most differentially expressed proteins were associated with inflammatory action and immunological processes.

\section{Differentially expressed proteins related to blood $\mathrm{Ca}$ concentration}

Two of the up-regulated proteins were identified as potentially related to blood $\mathrm{Ca}$ concentration, namely

Table 3 Proteins down-regulated among overlapping proteins

\begin{tabular}{lll}
\hline Gl number & Protein name & Mean fold change \\
\hline 155371855 & Platelet factor 4 precursor [Bos taurus] & 0.48 \\
45429979 & $\begin{array}{l}\text { Spleen trypsin inhibitor I precursor } \\
\text { [Bos taurus] }\end{array}$ & 0.54 \\
41386685 & $\begin{array}{l}\text { Thrombospondin-1 precursor [Bos } \\
\text { taurus] }\end{array}$ & 0.63 \\
\hline
\end{tabular}

GI (genlnfo identifier). Proteins with a mean value greater than 1.5 are considered up-regulated, while those with a mean value lower than 0.67 are considered down-regulated cadherin and periostin. Cadherin is a single chain transmembrane glycoprotein involved in cell adhesion, forming adherens junctions and binding cells together within tissues, and its activity is Ca dependent. Cadherin plays an important role in the formation of osteoblasts and bone by controlling adhesion and interaction between cells $[6,8,9]$, and it has also been linked to cell recognition and sorting, boundary formation and maintenance, coordination of cell motility, and maintenance of cell structure [10]. Meanwhile, the 811 amino acid periostin induces cell adhesion and separation, and members of the periostin family are characterized by a cysteine-rich $\mathrm{N}$-terminal region [11]. Studies have indicated that periostin is a novel member of the vitamin K-dependent gamma-carboxylate protein family [12]. Periostin is involved in both normal physiological and pathological processes, including vascular disease [13], trauma repair [14], bone formation [15] and formation of tumours [16]. Our GO analysis results indicated that cadherin and periosteal cells function in cell adhesion and protein binding.

In general, clinical hypocalcaemia $(\mathrm{CH})$ is diagnosed based on clinical signs and blood $\mathrm{Ca}$ concentration. However, accurate diagnosis of $\mathrm{SH}$ in dairy cows, which has been linked to various diseases affecting productivity 
in transition dairy cows, depends on the measurement of blood calcium. Up-regulation of the Ca-associated cadherin and periostin in $\mathrm{SH}$ suggests these proteins may initiate a mechanism that stimulates blood $\mathrm{Ca}$ when levels are decreased. The exact mechanism through which these proteins operate in dairy cows with $\mathrm{SH}$ requires further study.

\section{Differentially expressed proteins related to immune response and inflammatory reaction}

$\mathrm{SH}$ is a well-characterised metabolic disease which has the high prevalence in the first week of lactation in dairy cows [17] and the high incidence of peripartum problems in dairy cows. Furthermore, immune cells in cows with SH display impaired function [18]. Our bioinformatics analysis indicated that most proteins differentially expressed in diseased animals were related to immune response and inflammatory reaction. These included serum amyloid A protein and haptoglobin. Haptoglobin is an acidoglycoprotein that is highly expressed in blood and is believed to act as a cytokine following release from activated macrophages during the initial stages of pathogenic infection and tissue damage, which can stimulate the liver to produce acute phase reactive protein. Expression of haptoglobin in the blood is increased during stress or following pathogen-induced damage [19].

Serum amyloid A is mainly synthesized by the liver and can exist in acute phase amyloid A and structural amyloid protein forms. Expression of serum amyloid A can be up-regulated 100-fold within 1-2 days of an organism suffering from physical damage, stress or microbial infection [20]. As mentioned above, dairy cows with $\mathrm{SH}$ show no obvious clinical signs. However, our results indicated that diseased animals do show hypoimmunity. Dairy cows with metabolic diseases such as $\mathrm{SH}$ are therefore more likely to contract other more debilitating infectious and non-infectious diseases that could greatly influence production performance.

\section{Differentially expressed proteins related to blood coagulation and complement pathways}

Previous studies on $\mathrm{CH}$ and $\mathrm{SH}$ in dairy cows reported that the occurrence of $\mathrm{CH}$ is related to blood coagulation and complement pathways [3, 21-23], and our results are consistent with this observation. A number of differentially expressed proteins identified in the present study were related to blood coagulation and complement pathways, specifically platelet factor, serpin and complement factor. Complement and coagulation pathway proteins such as serpins and complement factors are known to be highly dependent on the plasma Ca concentration $[24,25]$. Serpins play an important role in coagulation, fibrinolysis and the protection of neurons, while platelet factors assist adhesion and aggregation of platelets, and accelerate blood coagulation. Many complement factors also stimulate the production of specific antibodies and therefore boost the immune system. Complement activation ultimately results in the formation of membrane attack complexes that attack and kill pathogenic microorganisms [26]. Ca is an important factor in blood coagulation, and malfunctions can occur if the blood $\mathrm{Ca}$ concentration is reduced. In this study, we identified a number of differentially expressed proteins involved in coagulation and complement pathways. We speculate that reduced blood $\mathrm{Ca}$ in dairy cows with $\mathrm{SH}$ may alter key metabolic and immunological pathways, and lead to diminished production performance and hypoimmunity. These results therefore indicate that $\mathrm{CH}$ and $\mathrm{SH}$ could serve as recognizable risk factors for diseases affecting productivity in dairy cows such as mastitis, ketosis, retained placenta, displaced abomasum and uterine prolapse [27].

\section{Conclusion}

In this study, we identified proteins that were differentially expressed in dairy cows with $\mathrm{SH}$ through a combined proteomics and bioinformatics approach. A total of 398 differentially expressed proteins were obtained, of which 24 were statistically significant and confirmed by MS. These proteins were mainly associated with blood $\mathrm{Ca}$ concentration, coagulation and complement pathways. Our results provide novel insight into $\mathrm{SH}$ in dairy cows.

\section{Abbreviations \\ ACN: Acetonitrile; Ca: Calcium; CH: Clinical hypocalcaemia; DCAD: Dietary cation anion difference; FA: Formaldehyde; SCX: Strong cation exchange;} $\mathrm{SH}$ : Subclinical hypocalcaemia

Acknowledgment

The authors thank the participating farmers.

Funding

This study was supported by the National Science and Technology Foundation of China (Grant number 30972235), the Heilongjiang Province Nature Science and Technology Foundation of China (Grant number C200916), the Chinese National Science and Technology Project of China (Grant number 2013BAD21B01-2) and the Natural Science Foundation of Heilongjiang Province of China (Grant number C2016041).

Availability of data and supporting materials Not applicable.

Authors' contributions

ZLF carried out the final analysis and drafted the manuscript. CX assisted in the analysis and helped to draft the manuscript. SS, CCX, LYB, XHX and GW collected data at dairy farms and carried out initial analysis. HYZ, CX, LW and WY participated in the design of the study and helped to draft the manuscript. All authors read and approved the final manuscript.

\section{Competing interests}

None of the authors of this paper has a financial or personal relationship with other people or organisations that could inappropriately influence or bias the content of the paper. The authors declare that they have no competing interests. 


\section{Consent for publication}

Not applicable.

\section{Ethics approval and consent to participate}

The study was approved by the farm owner and all animal experiments were conducted according to the International Guiding Principles for Biomedical Research. The protocol was approved by the Committee on the Ethics of Animal Experiments of the Heilongjiang Bayi Agricultural University.

\section{Received: 6 August 2016 Accepted: 11 January 2017}

Published online: 18 January 2017

\section{References}

1. Vansaun RJ, Sniffen CJ. Nutritional management of the pregnant dairy cow to optimize health, lactation and reproductive performance. Anim Feed Sci Tech. 1996;59(1):13-26.

2. Wang PX, Shu S, Xia C, Wang Z, Wu L, Wang B, et al. Protein expression in dairy cows with and without subclinical hypocalcaemia. New Zeal Vet J. 2015;64(2):1-15

3. Shu S, Xia C, Zhang HY, Sun ZL, Liu JN, Wang B. Plasma proteomics analysis of dairy cows with milk fever using SELDI-TOF-MS. Asian J Anim Vet Adv. 2014;9(1):1-12.

4. Xia C, Zhang HY, Wu L, Xu CC, Zheng JS, Yan Y, et al. Proteomic analysis of plasma from cows affected with milk fever using two-dimensional differential in-gel electrophoresis and mass spectrometry. Res Vet Sci. 2011; 93(2):857-61.

5. Paweletz CP, Trock B, Pennanen M, Tsangaris T, Magnant C, Liotta LA, et al. Proteomic patterns of nipple aspirate fluids obtained by SELDI-TOF: potential for new biomarkers to aid in the diagnosis of breast cancer. Dis Markers. 2000;17(4):301-7.

6. Schambony A, Kunz M, Gradl D. Cross-regulation of Wht signaling and cell adhesion. Differentiation. 2004;72(7):307-18

7. Edmondson IJ, Lean IJ, Weaver LD, Farver T, Webster G. A body condition scoring chart for Holstein Dairy Cows. J Dairy Sci. 1989;72(1):68-78.

8. Bienz M. $\beta$-Catenin: a pivot between cell adhesion and Wnt signalling. Curr Biol. 2005:15(2):R64-7.

9. Brembeck FH, Rosário M, Birchmeier W. Balancing cell adhesion and Wnt signaling, the key role of $\beta$-catenin. Curr Opin Genet Dev. 2006;16(1):51-9.

10. Halbleib JM, Nelson WJ. Cadherins in development: cell adhesion, sorting, and tissue morphogenesis. Gene Dev. 2006;20(23):3199-214.

11. Liu GX, Xi HQ, Sun XY, Wei B. Role of periostin and its antagonist PNDA-3 in gastric cancer metastasis. World J Gastroenterol. 2015;21(9):2605-13.

12. Coutu DL, Wu JH, Monette A, Rivard G-É, Blostein MD, Galipeau J. Periostin, a member of a novel family of vitamin K-dependent proteins, is expressed by mesenchymal stromal cells. J Biol Chem. 2008;283(26):17991-8001.

13. Stanton LW, Garrard LJ, Damm D, Garrick BL, Lam A, Kapoun AM, et al. Altered patterns of gene expression in response to myocardial infarction. Circ Res. 2000;86(9):939-45.

14. Roy S, Patel D, Khanna S, Gordillo GM, Biswas S, Friedman A, et al. Transcriptome-wide analysis of blood vessels laser captured from human skin and chronic wound-edge tissue. Proc Natl Acad Sci U S A. 2007;104(36): 14472-7.

15. Kruzynska FA, Wang JM, Maeda M, Rogers R, Krug E, Hoffman S, et al. Periostin is expressed within the developing teeth at the sites of epithelialmesenchymal interaction. Dev Dynam. 2004;229(4):857-68.

16. Kudo Y, Siriwardena B, Hatano H, Ogawa I, Takata T. Periostin: novel diagnostic and therapeutic target for cancer. Histol Histopathol. 2007;22(10): 1167-74.

17. Reinhardt TA, Lippolis JD, McCluskey BJ, Goff JP, Horst RL. Prevalence of subclinical hypocalcemia in dairy herds. Vet J. 2011;188:122-4.

18. Martinez N, Sinedino LDP, Bisinotto RS, Ribeiro ES, Gomes GC, Lima FS, et al. Effect of induced subclinical hypocalcemia on physiological responses and neutrophil function in dairy cows. J Dairy Sci. 2014;97(2):874-87.

19. Jung SM, Lee K, Lee JW, Namkoong H, Kim HK, Kim S, et al. Both plasma retinol-binding protein and haptoglobin precursor allele 1 in CSF: candidate biomarkers for the progression of normal to mild cognitive impairment to Alzheimer's disease. Neurosci Lett. 2008;436(2):153-7.

20. Bahk YY, Na BK, Cho S, Kim JY, Lim KJ, Kim TS. Proteomic analysis of haptoglobin and amyloid A protein levels in patients with vivax malaria. Korean J Parasitol. 2010;48(3):203-11.
21. Goff JP. The monitoring, prevention, and treatment of milk fever and subclinical hypocalcemia in dairy cows. Vet J. 2008;176(1):50-7.

22. Horst RL, Jorgensen NA. Elevated plasma cortisol during induced and spontaneous hypocalcemia in ruminants. J Dairy Sci. 1982;65(12):2332-7.

23. Ducusin RJT, Uzuka Y, Satoh E, Otani M, Nishimura M, Tanabe S, et al. Effects of extracellular Ca 2+ on phagocytosis and intracellular Ca $2+$ concentrations in polymorphonuclear leukocytes of postpartum dairy cows. Res Vet Sci. 2003;75(1):27-32.

24. Beinrohr L, Murrayrust TA, Dyksterhuis L, Zavodszky P, Gal P, Pike RN, et al. Serpins and the complement system. Method Enzymol. 2011;499:55-75.

25. Amara U, Rittirsch D, Flierl M, Bruckner U, Klos A, Gebhard F, et al. Interaction between the coagulation and complement system. Adv Exp Med Biol. 2008;632(2):71-9.

26. Onat A, Can G, Rezvani R, Cianflone K. Complement C3 and cleavage products in cardiometabolic risk. Clin Chim Acta. 2011:412(13-14):1171-9.

27. DeGaris PJ, Lean IJ. Milk fever in dairy cows: a review of pathophysiology and control principles. Vet J. 2008;176(1):58-69.

\section{Submit your next manuscript to BioMed Central and we will help you at every step:}

- We accept pre-submission inquiries

- Our selector tool helps you to find the most relevant journal

- We provide round the clock customer support

- Convenient online submission

- Thorough peer review

- Inclusion in PubMed and all major indexing services

- Maximum visibility for your research

Submit your manuscript at www.biomedcentral.com/submit
) Biomed Central 